\title{
A grid interconnected nested neutral point clamped inverter with voltage synchronization using synchronous reference frame controller
}

\author{
Bogimi Sirisha \\ Department of Electrical Engineering, University College of Engineering (A), Osmania University, Hyderabad, India
}

\begin{tabular}{l}
\hline \hline Article Info \\
\hline Article history: \\
Received Aug 30, 2021 \\
Revised Oct 29, 2021 \\
Accepted Nov 19, 2021 \\
\hline
\end{tabular}

Keywords:

Maximum power point tracking algorithm

Photovoltaic array

Point of common coupling

Pulse width modulation

Synchronous reference frame

\section{Corresponding Author:}

Bogimi Sirisha

Department of Electrical Engineering, University College of Engineering (A)

Osmania University

Osmania University Main Rd, Amberpet, Hyderabad, Telangana 500007, India

Email: sirishab@osmania.ac.in

\begin{abstract}
Nested neutral point clamped multi level inverter with inter connection to grid through the synchronous reference frame (SRF) controller for synchronization of voltage to the grid is demonstrated. The system's main feature is that voltage stress in each inverter switching device is kept to a minimum, and redundant inverter switching states are utilised for neutral point and flying capacitor voltage balancing with sinusoidal pulse-width modulation (PWM) technique, synchronisation to grid voltages, and power injection with low harmonic generation. The inverter receives its input from a photovoltaic (PV) source that is coupled to DC-DC booster converters that are regulated by the maximum power point tracking (MPPT) incremental conductance algorithm to maintain a constant dc voltage. The system is examined under various load conditions with MATLAB Simulink model.
\end{abstract}

This is an open access article under the $\underline{C C B Y-S A}$ license.

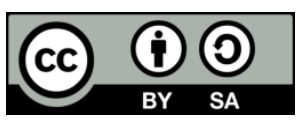

\section{INTRODUCTION}

Increased consumption of power by diverse loads throughout the world is causing demand for electrical power generation to increase day by day. Traditional methods (diesel generators, thermal plants, and nuclear plants) of larger production of electric power is causing the devastating effects of the environment. As a result of these methods of production, hazardous waste and gases are produced. Which inturn these power plants play a vital role for increase in global warming making earth a bad place for survival of living things on the planet. Better energy generation from renewable sources is the only way to safeguard the earth and make it a better place in the future [1]. Hydropower plants, solar power plants, wind farms, biogas facilities, and tidal wave units are examples of these types of generators. Wind farms, which generate large amounts of electricity yet may be constructed in remote places distant from civilization, are an instant alternative for hydro power plants. Solar power plants are the best alternative for generating large or little amounts of electricity. Sun plants are made up of a series of photovoltaic planes that use solar irradiation to create DC electricity. Photovoltaic arrays are different parallel and series configurations of these panels (PVA) [2]-[6]. Because the loads run on AC voltage, the DC power from the photovoltaic array must be converted to either single phase AC or three phases AC. Multi level inverter involves a key role in the process of conversion [7]. Extensive research on process of conversion using wide converters for higher efficiency and lower harmonic generation [8]-[10]. In this paper a nested neutral point clamped five level voltage source inverter [11] is inter connected to grid by using synchronous reference frame (SRF) controller. 
The renewable energy input is obtained by means of photovoltaic array through a DC-DC booster converter controlled by incremental conductance maximum power point tracking (MPPT) technique, so that, dc output obtained is stabilized by injecting power with low harmonic distortion [12]. The prototype model and analysis of the system is carried out under various conditions of load. Section 1 presents the nested neutral point clamped converter, section 2 describes the SRF control structure, section 3 gives PVA module with MPPT algorithm, and section 4 presents the results of the proposed system at different load conditions. The final section 5 has conclusions.

\section{NESTED NEUTRAL POINT CLAMPED INVERTER}

Nested neutral point clamped (NNPC) inverter is shown in Figure 1. The topology has eight switches in each leg. Output voltage levels for the switching are created by the voltage dividing capacitors $\mathrm{C} 1, \mathrm{C} 2$, and $\mathrm{C} 3$ [6]. The main feature is that, that the number of diodes andcapacitors for clamping are minimised. The converter also does not need any isolated DC source at the input for regenerative applications. Also, the interconnected capacitors create stabilized output voltages with reduced overshoots in the output [13]-[16]. The capacitors $\mathrm{Cn} 1$ and $\mathrm{Cn} 2(\mathrm{n}=\mathrm{a}, \mathrm{b}, \mathrm{c})$ are charged to a voltage of $1 / 4 \mathrm{Vdc}$ and the capacitor $\mathrm{Cn} 3$ is charge to voltage of $3 / 4 \mathrm{Vdc}$.

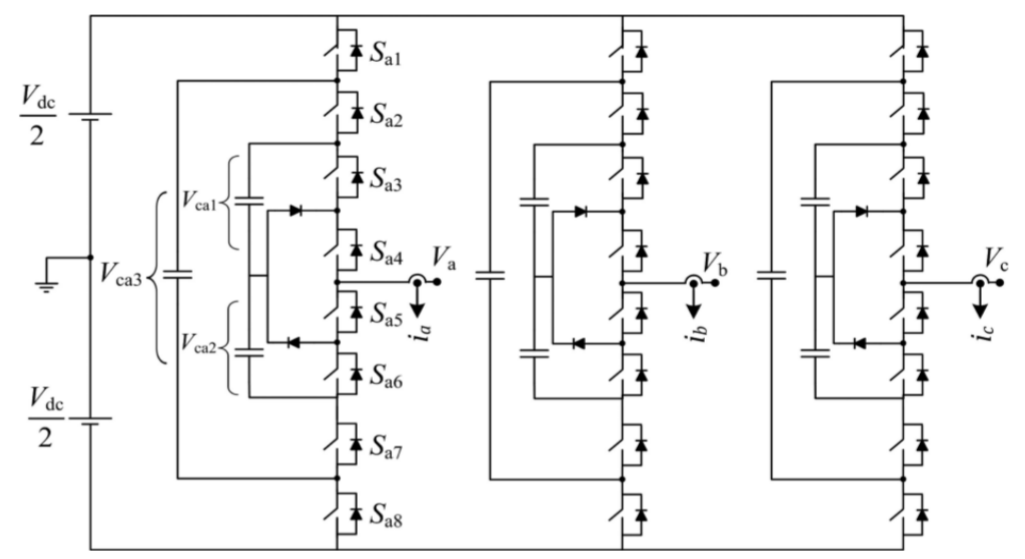

Figure 1. Five level NNPC inverter topology

The five level voltages including zero voltage are generated as per the switching of the eight switches of one leg. The zero voltage level includes charging and discharging of capacitors for achieving capacitor voltage balancing making the converter redundancy to voltage variations. The relation between $\mathrm{V}_{\mathrm{k}}$ and $\mathrm{L}_{\mathrm{k}}$ can be given as (1).

$$
V k=(4 L k-8) * \operatorname{Vin} / 16
$$

In-phase disposition (PD) carrier modulation technique [17], [18] is employed for the generation of pulses. In this method all the carrier waveforms are in phase with no phase shift. The reference sin waveform for the above PD modulation technique is generated by SRF controller which generates reference signal in synchronization to the grid.

\subsection{Capacitor voltages}

Redundant switching states at levels 1,2, and 3 to charge and discharge flying capacitors. But, there are not any redundancy switching states at 0,4 levels. Again, level 1 is nice to control voltages of capacitor $\mathrm{C}_{\mathrm{x} 3}$ and $\mathrm{C}_{\mathrm{x} 2}$, and further level 3 is good to control the voltage of capacitors $\mathrm{C}_{\mathrm{x} 3}$ and $\mathrm{C}_{\mathrm{x} 1}$. Further, there are redundancy states for levels 1, 2, and 3. Each redundancy state based on direction of output current can charge or discharge 3 flying capacitors. Thus, minimize the difference between nominal voltage values and measured voltage values. The flowchart of Figure 2 illustrates the process to control voltage of flying capacitors in each phase.

The synchronous reference frame (SRF) controller [19] is major module in the proposed test system which controls the output voltage of the multilevel inverter. For the output voltage match to the grid voltage 
amplitude, phase and frequency the SRF controller takes feedback [20] from the grid three phase voltages, currents and DC link voltage at the input. The structure of the SRF controller is given in Figure 3.

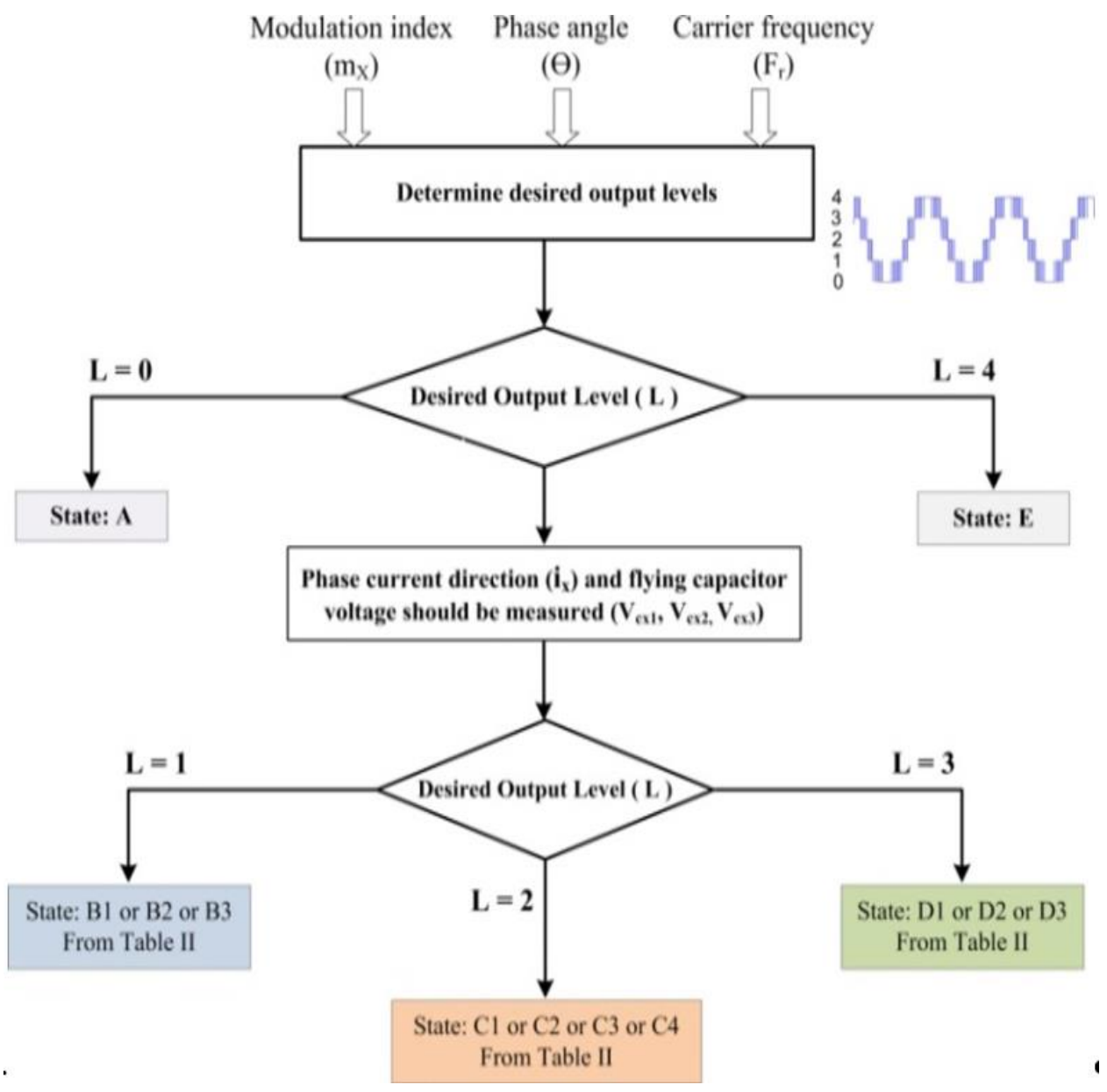

Figure 2. Flowchart to control the voltage of flying capacitor

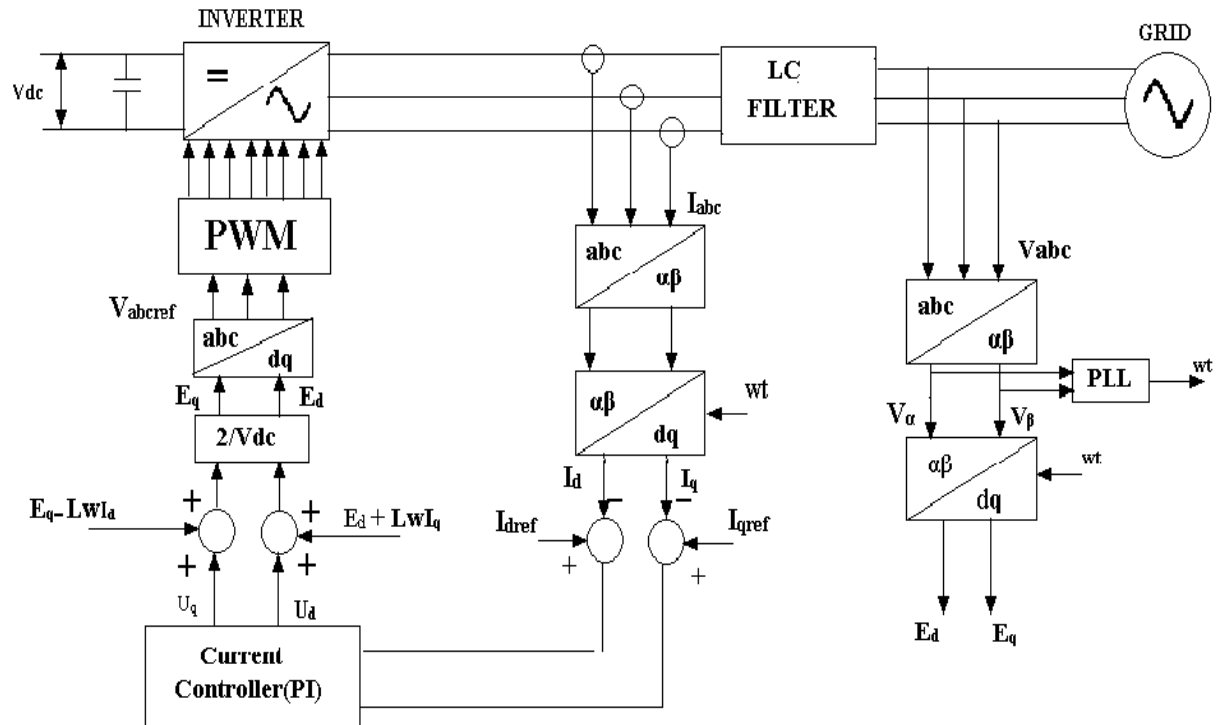

Figure 3. Block diagram of SRF control structure for PVA grid interconnection 
The SRF controller uses Parks transformation for controlling the current of the inverter. The dq components of the currents are calculated with respect to PLL module [19]-[25] working in synchronization to the grid voltage. The dq axis calculation for the given controller is given as per the equations given below. Let $r$ vector in abc coordinate system, angle between $a b, a b$, and ca are 120 degrees.

$$
\vec{r}=\mathrm{r}_{\mathrm{a}} \cdot \hat{a}+\mathrm{r}_{\mathrm{b}} \cdot \hat{b}+\mathrm{r}_{\mathrm{c}} \cdot \hat{c}
$$

Where, $r_{a}, r_{b}$, and $r_{c}$ be projections of $r$ vector in direction of $a, b$, and $c$.

$$
\vec{r}=\mathrm{r}_{\alpha} \cdot \hat{\alpha}+\mathrm{r}_{\beta} \cdot \hat{\beta}
$$

Where, $r_{\alpha}$ projection of $r$ vector in direction of $\alpha, r_{\beta}$ projection of $r$ vector in direction of $\beta$. To get relation between $\alpha \beta$ and abc:

$$
\begin{aligned}
& r \alpha=\vec{r} \cdot \hat{\alpha} \\
& r \alpha=\{r a \cdot \hat{a}+r b \cdot \hat{b}+r c \cdot \hat{c}\} \cdot \hat{\alpha} \\
& =r a \hat{a} \cdot \hat{\alpha}+r b \hat{b} \cdot \hat{\alpha}+r c \hat{c} \cdot \hat{\alpha} \\
& =r a+r b \cos (1200)+r c \cos (2400) \\
& r \alpha=r a-\frac{1}{2} r b-\frac{1}{2} r c
\end{aligned}
$$

$\mathrm{r}_{\beta}$ projection of $\mathrm{r}$ vector in the direction of $\beta$ is

$$
\begin{aligned}
& r \beta=\vec{r} \cdot \hat{\beta} \\
& r \beta=\{r a \cdot \hat{a}+r b \cdot \hat{b}+r c \cdot \hat{c}\} \cdot \hat{\beta} \\
& =r a \hat{a} \cdot \hat{\beta}+r b \hat{b} \cdot \hat{\beta}+r c \hat{c} \cdot \hat{\beta} \\
& =r a+r b \cos (300)+r c \cos (1500) \\
& r \beta=0+\frac{\sqrt{3}}{2} r b-\frac{\sqrt{3}}{2} r c \\
& {\left[\begin{array}{c}
r \alpha \\
\mathrm{r} \beta \\
\mathrm{r} 0
\end{array}\right]=\left[\begin{array}{ccc}
1 & -\frac{1}{2}-\frac{1}{2} \\
0 & \frac{\sqrt{3}}{2}-\frac{\sqrt{3}}{2} \\
\frac{1}{\sqrt{2}} \frac{1}{\sqrt{2}} \frac{1}{\sqrt{2}}
\end{array}\right]\left[\begin{array}{c}
\mathrm{ra} \\
\mathrm{rb} \\
\mathrm{rc}
\end{array}\right]} \\
& {\left[\begin{array}{c}
\vec{r} \mathrm{~d} \\
\vec{r} \mathrm{q} \\
0
\end{array}\right]=\left[\begin{array}{c}
\cos \theta \sin \theta 0 \\
-\sin \theta \cos \theta 0 \\
001
\end{array}\right]\left[\begin{array}{c}
\vec{r} \alpha \\
\vec{r} \beta \\
0
\end{array}\right]}
\end{aligned}
$$

By using Clarks transformation and from $\alpha \beta$-coordinates to dq-coordinates (Parks transformation) we get

$$
\left[\begin{array}{c}
\overrightarrow{\mathrm{r}} \mathrm{d} \\
\overrightarrow{\mathrm{r}} \mathrm{q} \\
0
\end{array}\right]=\sqrt{\frac{2}{3}}\left[\begin{array}{ccc}
\cos \theta & \frac{-1}{2} \cos \theta+\frac{\sqrt{3}}{2} \sin \theta & \frac{-1}{2} \cos \theta-\frac{\sqrt{3}}{2} \sin \theta \\
-\sin \theta & \frac{1}{2} \sin \theta+\frac{\sqrt{3}}{2} \cos \theta & \frac{1}{2} \sin \theta-\frac{\sqrt{3}}{2} \cos \theta \\
\frac{1}{\sqrt{2}} & \frac{1}{\sqrt{2}} & \frac{1}{\sqrt{2}}
\end{array}\right]
$$

The voltage controller is a PI controller with input taken by comparison of DC voltage at the DC link capacitor and reference value given by the user. The output of the voltage controller is direct axis component reference and quadrature axis reference component is considered to be 0 . The current controller generates the required reference dq voltage reference component with PI controller in it. The reference dq voltage components $\left(\mathrm{Vd}^{*}\right.$ and $\left.\mathrm{Vq}^{*}\right)$ [19] are converted to sinusoidal by inverse parks transformation. The final three phase sinusoidal reference waveforms are compared to phase disposition multi carrier modulation technique for generation of pulses for the novel five level inverter. As the SRF controller uses PLL to generate the reference signals and the PLL is operated with grid voltage as feedback, the inverter operates in synchronization with the grid. 


\section{PVA-MODULE}

The PVA is a DC source which generates power by converting solar irradiation. The DC voltage from the PVA is not always constant as the solar irradiation is variable with change in climaticconditions. For constant DC voltage generation, the PVA is connected to a stabilizing DC-DC booster converter controlled by MPPT technique [22] for maintaining the output voltage at a specified value. A DC-DC booster converter is utilized for this purpose so as to increase the input voltage to the inverter as the AC loads operate at high voltages. The duty ratio for the IGBT switch is generated by incremental conductance MPPT algorithm [20]-[25]. This algorithm is considered to be robust and operates with faster response rate as compared to traditional P\&O MPPT algorithm which is used in most of the MPPT techniques.

\section{RESULTS AND DISCUSSION}

The prototype of PVA renewable source connected to nested neutral point clamped five level inverter controlled by SRF controller interconnected to three phase grid is modelled is simulated MATLAB Simulink. The parameters of simulation are given in Table 1.

Table 1. Parameters of Simulink block diagram

\begin{tabular}{|c|c|}
\hline Parameter & Value \\
\hline Input dc link voltage & Vin $=600 \mathrm{~V}$ \\
\hline Switching frequency & $\mathrm{F}_{\mathrm{sh}}=2000 \mathrm{~Hz}$ \\
\hline Diode & Rin $=0.001 \mathrm{ohms}$, Forward voltage $=0.8 \mathrm{~V}$ \\
\hline Flying capacitor & $\mathrm{C}=1000 \mu \mathrm{F}$ \\
\hline IGBT switch & Rin $=0.001 \mathrm{ohms}$ \\
\hline Modulation index & $\mathrm{MI}=0.95$ \\
\hline Fundamental frequency & $\mathrm{F}=50 \mathrm{~Hz}$ \\
\hline Switching frequency & $\mathrm{Fs}=2000 \mathrm{~Hz}$ \\
\hline R-load & $\mathrm{R}=100 \mathrm{ohms}$ \\
\hline RL-load with 0.7 power factor lagging & $\mathrm{P}=700 \mathrm{~W}, \mathrm{Q}_{\mathrm{L}}=714.14 \mathrm{VAR}$ \\
\hline LC-filter & $\mathrm{L}=10 \mathrm{mH}, \mathrm{C}=810 \mu \mathrm{f}$ \\
\hline 3-phase breaker & $\begin{array}{l}\text { Breaking resistance }\left(\mathrm{R}_{\mathrm{ON}}\right)=0.01 \mathrm{ohms} \\
\text { Switching time }=0.1 \mathrm{sec} \text { for all } 3 \text { phases }\end{array}$ \\
\hline Frequency & $=50 \mathrm{~Hz}$ \\
\hline Poles & $=4$ \\
\hline (Rs) & $=0.55 \mathrm{ohms}$ \\
\hline (Ls) & $=0.00288 \mathrm{H}$ \\
\hline$(\mathrm{Rr})$ & $=0.78 \mathrm{ohms}$ \\
\hline (Lr) & $=0.00286 \mathrm{H}$ \\
\hline (Lm) & $=0.0905 \mathrm{H}$ \\
\hline Inertia $(J)$ & $=0.019 \mathrm{~kg}-\mathrm{m}^{2}$ \\
\hline Friction factor (B) & $=0.002985 \mathrm{Nm}-\mathrm{sec}$ \\
\hline \multicolumn{2}{|c|}{ Rating of grid connected } \\
\hline $\mathrm{Ph}-\mathrm{Ph}$ voltage $\mathrm{RMS}$ & $=132 \mathrm{KV}$ \\
\hline 3-phase short circuit level at base voltage (VA) & $=2500 \mathrm{MVA}$ \\
\hline Frequency & $=50 \mathrm{~Hz}$ \\
\hline $\mathrm{X} / \mathrm{R}$ ratio & $=7$ \\
\hline \multicolumn{2}{|c|}{ Rating of transformers } \\
\hline Stepdown transformer 1 & $100 \mathrm{KVA}, 11 \mathrm{KV} / 260 \mathrm{~V}$ \\
\hline Stepdown transformer 2 & $47 \mathrm{MVA}, 132 \mathrm{KV} / 11 \mathrm{KV}$ \\
\hline Stepdown transformer 3 & $100 \mathrm{KVA}, 11 \mathrm{KV} / 400 \mathrm{~V}$ \\
\hline \multicolumn{2}{|c|}{ Ratings of LC-fitter } \\
\hline Resistance $\left(\mathrm{R}_{\mathrm{L}}\right)$, Inductance $(\mathrm{L})$ & $=3.14 \mathrm{mOhms}, 0.5 \mathrm{mH}$ \\
\hline Active power $(\mathrm{P})$, Reactive power $\left(\mathrm{Q}_{\mathrm{C}}\right)$ & $=100 \mathrm{~W}, 10 \mathrm{KVAR}$ \\
\hline
\end{tabular}

Figure 4 shows the Simulink diagram of prototype model with SRF controller with induction motor load. Figure 5 shows the output voltages of Nested neutral point clamped inverter with 0.95 modulation index. Figure 6 shows the three phase line voltages Vabc of NNPC inverter which is sinusoidal, but Iabc is "M-W type" sinusoidal current because system is connected to non-linear load across the 3-phase power supply. 


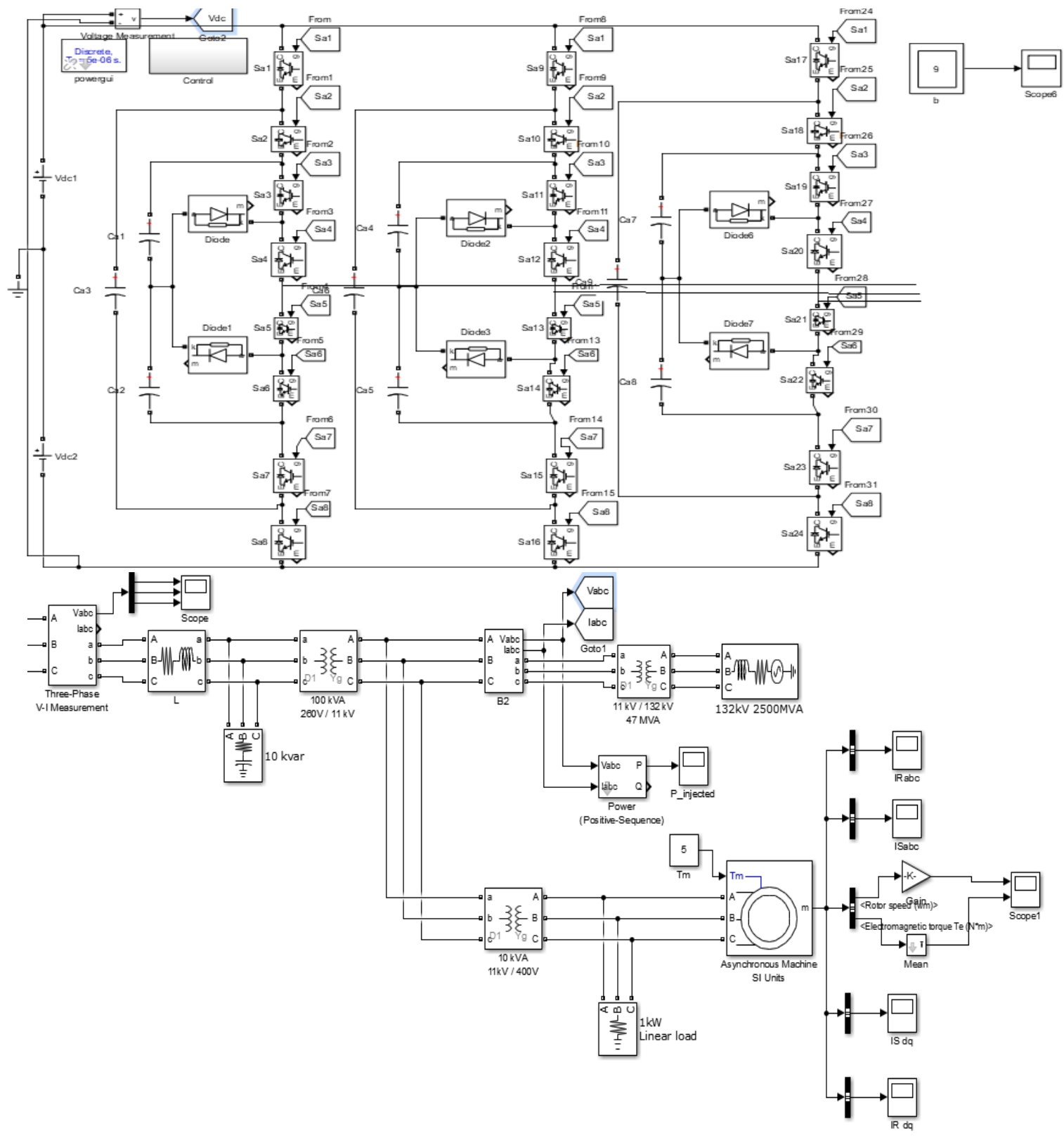

Figure 4. Simulink diagram with SRF controller with induction motor load

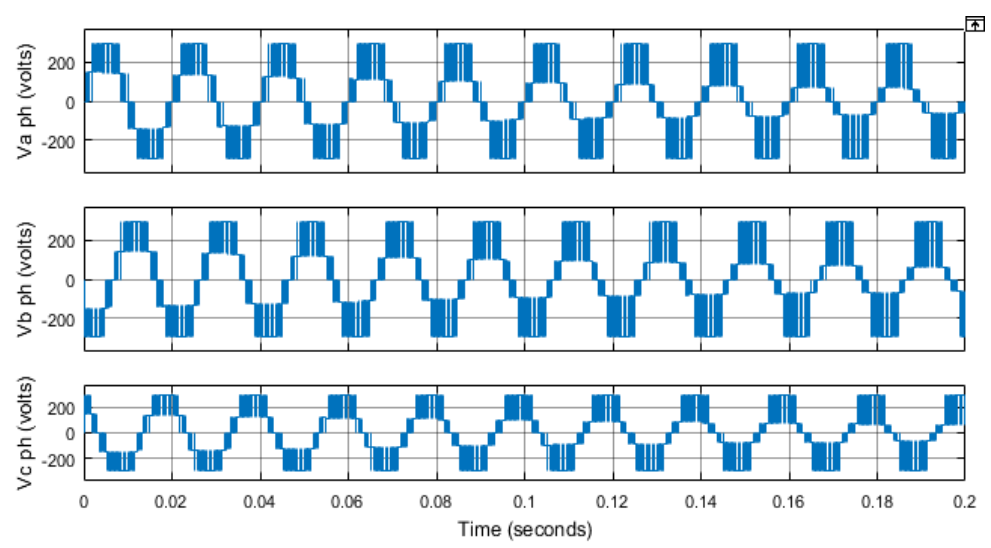

Figure 5. Five level output voltage for modulation index $=0.95$ with $\mathrm{R}-\mathrm{Load}(\mathrm{R}=100 \Omega)$ 

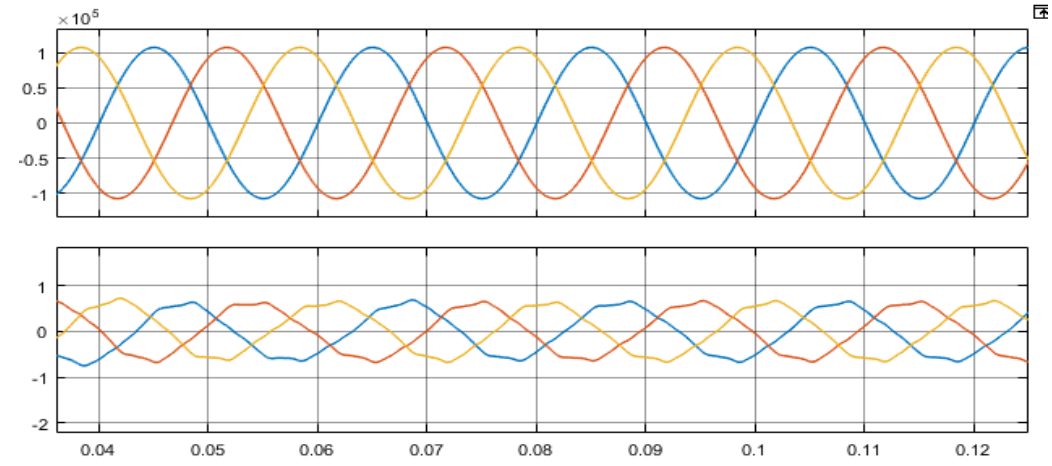

Figure 6. Grid voltage and grid current

Induction motor-load:

$\mathrm{T}_{\mathrm{a}}=$ Gross mechanical torque (or) motor torque

$\mathrm{T}_{\mathrm{sh}}$ (or) $\mathrm{T}_{\mathrm{L}}=$ Load torque

$\mathrm{T}_{\text {loss }}=$ Loss due to friction, windage, and iron losses.

$$
\begin{aligned}
& \text { Ta }=\text { Tloss }+ \text { Tsh Power }(\text { Pout })=\text { Tsh } * W \\
& \text { Tsh }=\frac{\text { Pout }}{W}=\frac{10 * 746}{\frac{2 \pi * 1440}{60}}=49.47 \mathrm{~N}-\mathrm{m} . \text { Consider } 49.47 \mathrm{~N}-\mathrm{m} \text { as full load. }
\end{aligned}
$$

So, consider $24.73 \mathrm{~N}-\mathrm{m}$ as half-load, $12.36 \mathrm{~N}-\mathrm{m}$ as half-load, and $0 \mathrm{~N}-\mathrm{m}$ as no-load.

Figure 7 shows the variation of load torque applied. Figure 8 and Figure 9 shows as the load is decreased from full-load to half-load to quarter-load to no-load, the rotating magnetic field produced will also decrease. So, the current required to produce RMF is also decrease as shown Is_abc \& Ir_abc. (full-load started at $0.6 \mathrm{sec})$.

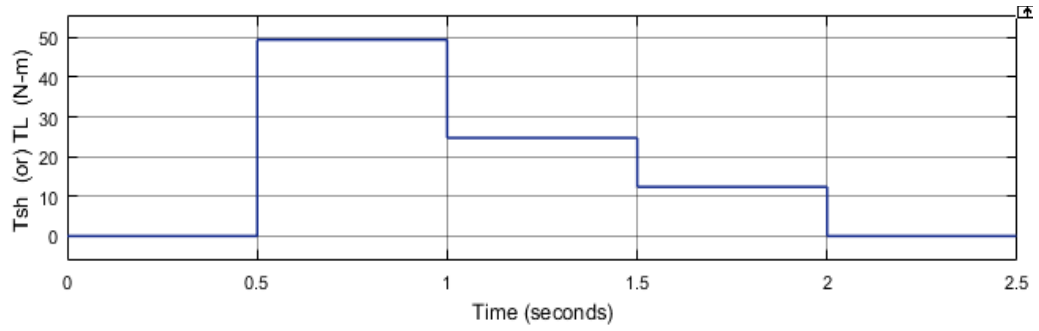

Figure 7. Load torque applied to induction motor
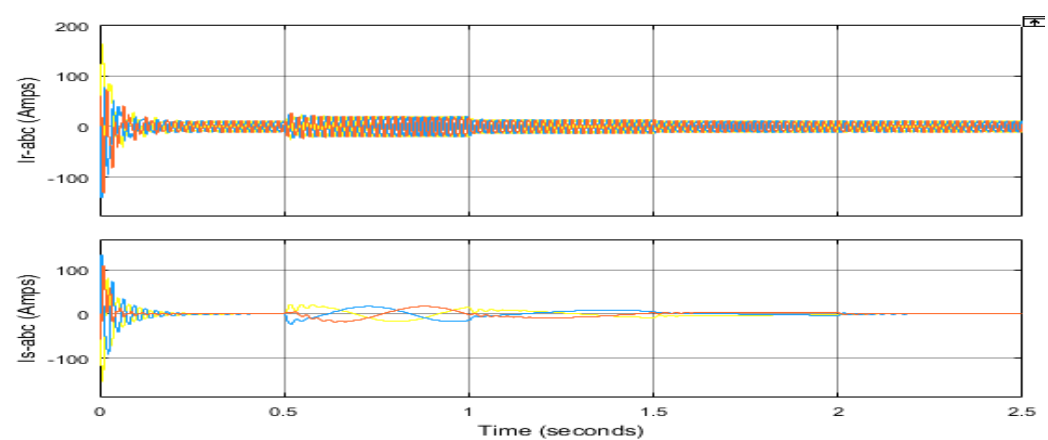

Figure 8. Stator and rotor currents $\mathrm{I}_{\mathrm{abc}}$ 

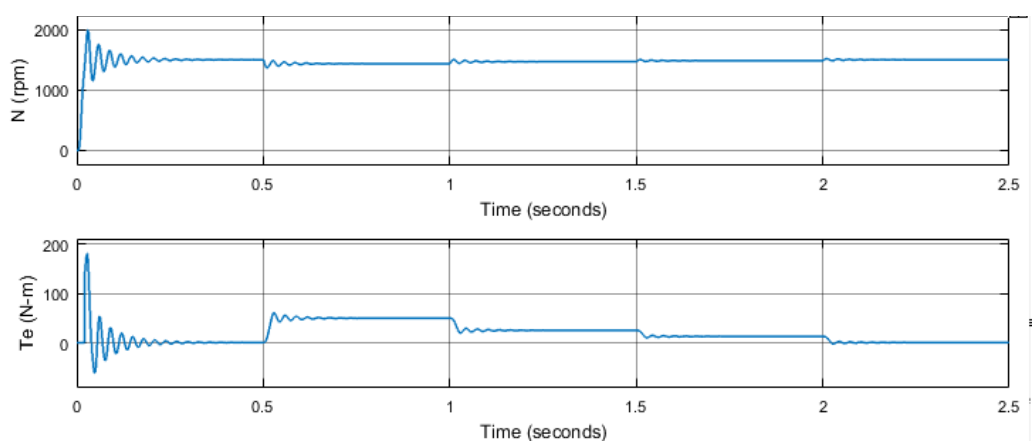

Figure 9. Speed, $\mathrm{T}_{\mathrm{e}}$ vs time

Table 2 shows \%THD of phase voltages at output for various types of loads without SRF controller THD obtained is higher, further THD is minimized by SRF controller there by eliminating the harmonics.

Table 2. Output phase voltage THD of inverterside for R, RL, and induction motor-load

\begin{tabular}{lcc}
\hline \multicolumn{1}{c}{ Case studies } & \multicolumn{2}{c}{ \% THD of Ph-Ph output voltage } \\
& Without SRF controller & With SRF controller \\
\hline R-Load & $25.35 \%$ & $0.06 \%$ \\
RL-Load & $48.75 \%$ & $0.07 \%$ \\
Induction motor-load & $308.19 \%$ & $0.05 \%$ \\
\hline
\end{tabular}

\section{CONCLUSION}

Nested neutral point clamped five level inverter interconnected to grid controlled by SRF structure with PD multi carrier modulation technique is analysed. The connection to grid by means of inverter is synchronized and the power from the PVA is injected to the system compensating the loads connected at PCC. The system is well tested for both static and dynamic load conditions. The results show the reduction of output phase voltage THDs within the permissible limit $(<1 \%)$. The system can be further extended with multiple renewable sources that can be connected at the input to the inverter and optimal controller can be incorporated for better voltage.

\section{REFERENCES}

[1] D. Lee and L. Wang, "Small-signal stability analysis of an autonomous hybrid renewable energy power generation/energy storage system part i: time-domain simulations," in IEEE Transactions on Energy Conversion, vol. 23, no. 1, pp. 311-320, Mar. 2008, doi: 10.1109/TEC.2007.914309.

[2] M. El malah, A. Ba-razzouk, M. Guisser, E. Abdelmounim, and M. Madark, "Backstepping based power control of a three-phase single-stage grid-connected PV system," International Journal of Electrical and Computer Engineering (IJECE), vol. 9, no. 6, pp. 4738-4748, Dec. 2019, doi: 10.11591/ijece.v9i6.pp4738-4748.

[3] A. Rahnamaei and M. Salimi, "A novel grid connected photovoltaic system," Bulletin of Electrical Engineering and Informatics, vol. 5, no. 2, pp. 133-143, Jun. 2016, doi: 10.11591/eei.v5i2.523.

[4] F. Blaabjerg, R. Teodorescu, M. Liserre, and A. V. Timbus, "Overview of control and grid synchronization for distributed power generation systems," in IEEE Transactions on Industrial Electronics, vol. 53, no. 5, pp. 13981409, Oct. 2006, doi: 10.1109/TIE.2006.881997.

[5] M. Liserre, R. Teodorescu, and F. Blaabjerg, "Stability of photovoltaic and wind turbine grid-connected inverters for a large set of grid impedance values," in IEEE Transactions on Power Electronics, vol. 21, no. 1, pp. 263-272, Jan. 2006, doi: 10.1109/TPEL.2005.861185.

[6] L. A. de S. Ribeiro, O. R. Saavedra, J. G. de Matos, S. L. Lima, G. Bonan, and A. S. Martins, "Design, control, and operation of a hybrid electrical generation system based on renewable energy sources," Revista Eletrônica de Potência-Sobraep, vol. 15, no. 4, pp. 313-322, 2010.

[7] V. Kaura and V. Blasko, "Operation of a phase locked loop system under distorted utility conditions," in IEEE Transactions on Industry Applications, vol. 33, no. 1, pp. 58-63, Jan.-Feb. 1997, doi: 10.1109/28.567077.

[8] Y. Zhang, G. P. Adam, T. C. Lim, S. J. Finney, and B. W. Williams, "Hybrid multilevel converter: capacitor voltage balancing limits and its extension," in IEEE Transactions on Industrial Informatics, vol. 9, no. 4, pp. 2063 2073, Nov. 2013, doi: 10.1109/TII.2012.2235846.

[9] S. R. Pulikanti and V. G. Agelidis, "Hybrid flying-capacitor-based active-neutral-point-clamped five-level converter operated with SHE-PWM," in IEEE Transactions on Industrial Electronics, vol. 58, no. 10, pp. 46434653, Oct. 2011, doi: 10.1109/TIE.2011.2106098. 
[10] R. B. Bollipo, S. Mikkili, and P. K. Bonthagorla, 'Hybrid, optimal, intelligent and classical PV MPPT techniques: A review," in CSEE Journal of Power and Energy Systems, vol. 7, no. 1, pp. 9-33, Jan. 2021, doi: 10.17775/CSEEJPES.2019.02720.

[11] K. Wang, Z. Zheng, Y. Li, K. Liu, and J. Shang, "Neutral-point potential balancing of a five-level active neutralpoint-clamped inverter," in IEEE Transactions on Industrial Electronics, vol. 60, no. 5, pp. 1907-1918, May 2013, doi: 10.1109/TIE.2012.2227898.

[12] T. Laagoubi, M. Bouzi, M. Benchagra, "MPPT \& power factor control for grid connected PV systems with Fuzzy logic controllers," International Journal of Power Electronics and Drive System (IJPEDS), vol. 9, no. 1, pp. 105113, Mar. 2018, doi: 10.11591/ijpeds.v9n1.pp105-113.

[13] Z. Xu, X. Zheng, T. Lin, J. Yao, and A. Ioinovici, "Switched-capacitor multi-level inverter with equal distribution of the capacitors discharging phases," in Chinese Journal of Electrical Engineering, vol. 6, no. 4, pp. 42-52, Dec. 2020, doi: 10.23919/CJEE.2020.000029.

[14] R. Abdullah, N. A. Rahim, S. R. S. Raihan, and A. Z. Ahmad, "Five-level diode-clamped inverter with three-level boost converter," in IEEE Transactions on Industrial Electronics, vol. 61, no. 10, pp. 5155-5163, Oct. 2014, doi: 10.1109/TIE.2013.2297315.

[15] S. Thielemans, A. Ruderman, B. Reznikov, and J. Melkebeek, "Improved natural balancing with modified phaseshifted PWM for single-leg five-level flying-capacitor converters," in IEEE Transactions on Power Electronics, vol. 27, no. 4, pp. 1658-1667, Apr. 2012, doi: 10.1109/TPEL.2011.2169993.

[16] M. Narimani, B. Wu, and N. R. Zargari, "A novel five-level voltage source inverter with sinusoidal pulse width modulator for medium-voltage applications," in IEEE Transactions on Power Electronics, vol. 31, no. 3, pp. 19591967, Mar. 2016, doi: 10.1109/TPEL.2015.2440656.

[17] W. Jiang, X. Huang, J. Wang, J. Wang, and J. Li, "A carrier-based PWM strategy providing neutral-point voltage oscillation elimination for multi-phase neutral point clamped 3-level inverter," in IEEE Access, vol. 7, pp. 124066124076, 2019, doi: 10.1109/ACCESS.2019.2938623.

[18] X. Quan and A. Q. Huang, "PI-based synchronous reference frame frequency-locked loop," in IEEE Transactions on Industrial Electronics, vol. 68, no. 5, pp. 4547-4553, May 2021, doi: 10.1109/TIE.2020.2985002.

[19] A. M. Diab et al., "Fast and simple tuning rules of synchronous reference frame proportional-integral current controller," in IEEE Access, vol. 9, pp. 22156-22170, 2021, doi: 10.1109/ACCESS.2021.3054845.

[20] F. M. González-Longatt, "Model of photovoltaic module in MATLAB," in 2do congresoiberoamericano de estudiantes de ingenierlacute eléctrica, electrónica y computación (ii cibelec 2005), 2005, pp. 1-5.

[21] S. Bhattacharyya, D. S. Kumar P, S. Samanta, and S. Mishra, "Steady output and fast tracking MPPT (SOFTMPPT) for P\&O and InC algorithms," in IEEE Transactions on Sustainable Energy, vol. 12, no. 1, pp. 293-302, Jan. 2021, doi: 10.1109/TSTE.2020.2991768.

[22] S. Selvakumar, M. Madhusmita, C. Koodalsamy, S. P. Simon, and Y. R. Sood, "High-speed maximum power point tracking module for PV systems," in IEEE Transactions on Industrial Electronics, vol. 66, no. 2, pp. 1119-1129, Feb. 2019, doi: 10.1109/TIE.2018.2833036.

[23] B. Sirisha, P. Satishkumar, "A simplified space vector PWM for cascaded H-bridge inverter including over modulation operation," 13th International IEEE India Conference INDICON 2016, at IISC, Bengaluru, India, Dec. 16-18, 2016, doi: 10.1109/INDICON.2016.7839038.

[24] B. Sirisha, P. Satishkumar, "Simplified space vector pulse width modulation based on switching schemes with reduced switching frequency and harmonics for five level cascaded H-bridge inverter," International Journal of Electrical and Computer Engineering, vol. 8, no. 5, pp. 3417-3426, 2017, doi: 10.11591/ijece.v8i5.pp3417-3426.

[25] B. Sirisha and P. S. Kumar, "SVPWM based generalized switching schemes for seven level DCMLI including over modulation operation-FPGA implementation," TENCON 2019 - 2019 IEEE Region 10 Conference (TENCON), 2019, pp. 2135-2142, doi: 10.1109/TENCON.2019.8929380.

\section{BIOGRAPHY OF AUTHOR}

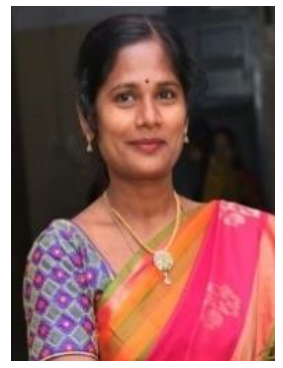

Bogimi Sirisha She holds a B.E. in Electrical Engineering from Osmania University, M. Tech Power Eelectronics from JNTUH in 2003, and a Ph.D. degree from Osmania University 2018. She has over 16 years of experience in research and teaching and is currently employed as an Associate Professor in Electrical Department, Engineering College, Osmania University, Hyderabad, India. She has published various articles in international and national journal publications and conferences. Multilevel Inverters, power electronics and drives, renewable energy applications and special electrical machines are among her research interests. Osmania University awarded her a Ph.D. in the field of multilevel inverters. 